\title{
SERUM LIPID AND LIPOPROTEIN ALTERATIONS IN NEPHROSIS
}

\author{
By JAMES H. BAXTER, HOWARD C. GOODMAN AND RICHARD J. HAVEL \\ (From the Laboratory of Cellular Physiology and Metabolism, National Heart Institute, \\ Bethesda, Md.)
}

(Submitted for publication September 15, 1959; accepted October 30, 1959)

When nephrosis was recognized as a clinical entity, an increased concentration of serum cholesterol was observed to be a consistent feature of the syndrome (1). Later it was found that phospholipid and triglyceride also are increased in nephrosis (2-5).

The increase in serum lipids in nephrosis is usually greatest in the cases with the lowest levels of serum albumin. It has not been established conclusively, however, that the hyperlipidemia is caused by hypoalbuminemia, and irregularities in the relationship between levels of serum lipids and serum albumin have been pointed out repeatedly (2-5).

After it was recognized that lipids exist in the serum in the form of lipoprotein macromolecules, techniques developed for the separation and characterization of proteins were applied to studies of lipoproteins. An abnormal distribution of cholesterol among the serum protein fractions precipitated by alcohol was found by Barr, Russ and Eder (6) in cases of nephrosis. Kunkel and Slater (7) observed an abnormal pattern of serum lipoproteins by zone electrophoresis-in part a result of increased quantities of unesterified fatty acid bound to the lipoproteins (8)-in nephrosis. Gofman, Rubin, McGinley and Jones (9) noted in nephrotic subjects that all classes of lipoproteins studied by them in the analytical ultracentrifuge $\left(S_{f} 0\right.$ to 400$)$ were increased.

In the present study lipoprotein fractions of sera from patients with nephrosis were isolated by the technique of ultracentrifugation at various densities and analyzed for lipids and protein. Levels of individual serum lipids are correlated with lipoprotein pattern, and also with serum lactescence and serum albumin concentration. It is emphasized that lipoprotein patterns of different sera may differ greatly even when serum cholesterol levels are the same.

\section{METHODS}

Subjects. Forty-four hospitalized patients with nephrosis or the nephrotic syndrome were studied. In a majority of cases the disease was considered to be idiopathic. There was one case of systemic lupus erythematosus (N.G.) and one of primary amyloidosis with renal involvement (M.K.). Symptoms of nephrosis in different cases ranged from severe to mild. Clinical features of many of the cases have been described in detail elsewhere (10). Most of the patients were ambulatory and were taking food satisfactorily. Sera obtained during periods of severe complications, experimental procedures, or therapy (other than sodium restriction and symptomatic care) were excluded. Likewise, sera obtained soon after admission to the hospital or soon after a change in clinical condition of the patient were excluded if the results were shown by repeated subsequent analyses to be aberrant. Results of analyses of 2 or 3 similar sera from the same patient are included in the tables in some instances but mean values for these duplicate sera are used in the charts and calculations. In the case of almost one-half of the patients, 2 or occasionally 3 dissimilar sera obtained in different stages of the disease, sometimes before and after complete or partial remissions, are included and counted individually. In a majority of cases the serum albumin and cholesterol levels which are recorded were shown by serial determinations to be approximately steady state values. Repeated determinations of the other lipids also were made in more than one-half of the cases.

Blood samples and analytical procedures. Blood specimens were taken by venipuncture about 7:30 a.m. after an overnight fast. Analyses of whole sera for lipids were made by methods previously employed in this laboratory $(11,12)$, using ethanol-acetone for extraction of lipids in the analyses done prior to 1956 and chloroform-methanol (13) in the more recent analyses. Total lipid was determined by the method of Bragdon (14), free and total cholesterol by the Schoenheimer-Sperry method (15), and lipid phosphorus by a modification of the method of Stewart and Hendry (16). Phospholipid was calculated as lipid phosphorus times 25 . Triglyceride was calculated by difference (14), with a correction for interference by nonlipid substances in cases of extracts made with ethanol-acetone (13). Serum albumin was determined by a modification of the dye interaction 
TABLE I

Serum lipoprotein fractions studied

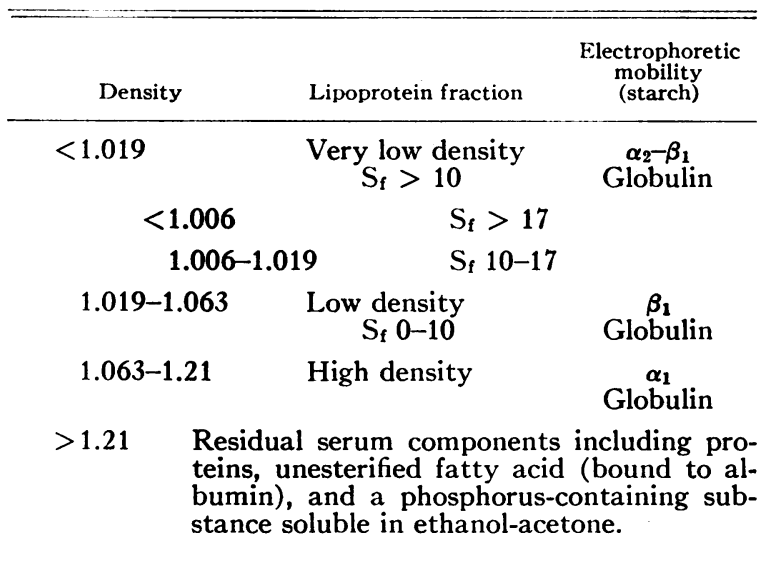

method of Rutstein, Ingenito and Reynolds (17), and checked in some cases by electrophoresis.

Lipoprotein fractions of the sera were isolated by preparative ultracentrifugation at various densities followed by separation of the supernatant from the infranatant material by slicing of the tubes (18). For this purpose $5 \mathrm{ml}$ aliquots of sera were adjusted successively to densities of $1.019,1.063$, and 1.21 by addition of solutions of sodium chloride and potassium bromide and centrifuged at $105,000 \times \mathrm{G}$ at $15^{\circ} \mathrm{C}$ in the no. 40 rotor of a Model L Spinco ultracentrifuge for 18,24 , and 48 hours successively $(11,12)$. In some cases an additional (initial) fractionation at density of 1.006 (D 1.006) was made, after dilution of the sera with $0.15 \mathrm{M}$ sodium chloride solution. The equivalent fractions obtained by other methods are shown in Table I. Protein was determined directly or after extraction of the fractions with ethanol-acetone by a biuret method (19) or by the method of Lowry, Rosenbrough, Farr and Randall (20). Lipids in the fractions were determined as described above for whole serum. The recoveries of cholesterol and phospholipid in the lipoprotein fractions averaged about 95 per cent of the quantities in the original sera. Triglyceride values for the D 1.019-1.063 and D 1.063-1.21 fractions are not shown but may be calculated approximately by assuming, respectively, that 25 and 17 per cent of total cholesterol was free.

The lipids and lipoprotein fractions in sera of normal young adults have been studied previously using the methods employed in this study (11-13). These normal values are utilized as a standard of reference for the present results. Ages of the patients varied but the abnormalities in lipid values were so great that normal variations with age were relatively unimportant.

RESULTS

\section{Serum lipids}

The sera are divided into two categories on the basis of total cholesterol (TC) concentration:
Category A with definitely increased lipids ( TC > $350 \mathrm{mg}$ per $100 \mathrm{ml}$ ), and Category B with normal or only slightly increased lipids (TC $<300 \mathrm{mg}$ per $100 \mathrm{ml}$ ). Results of analyses of sera of Category $\mathrm{A}$ are shown in Table II. Except for minor rearrangements in order to place together similar (duplicate) sera from the same patients, the sera are listed in order of decreasing concentrations of triglyceride. In listing the sera in this manner they are also arranged approximately in order of decreasing lactescence. For convenience of discussion, the seta of Category $\mathrm{A}$ are subdivided into four successive groups (Groups 1,2, 3 and 4). The description of the lipid and lipoprotein abnormalities which follows is based principally on observations on these sera.

The results of analyses of sera of Category Bthose with normal or slightly increased lipidsare shown in Table III. Some of these sera were obtained from patients with proteinuria of moderate degree (Group 5) and others were taken during periods of partial or complete remission of the disease with little or no proteinuria (Group 6). These slightly abnormal sera are included to complete the picture of the lipid alterations in nephrosis and to extend the range over which values of serum lipids and serum albumin may be correlated. The division of all the sera of the study into categories and groups is shown graphically in Figure 1, and mean results of analyses of the sera of the various groups are presented as multiples of normal values $(11,12)$ in Figure 2 .

Total cholesterol concentration as already noted was above $350 \mathrm{mg}$ per $100 \mathrm{ml}$ in all sera of Category A. Mean TC was greatest in Group 1 and progressively less in the other groups. The range of values in all groups of Category A overlapped, however, and mean values for Groups 2, 3 and 4 were not greatly different. Free cholesterol (FC) in all sera was increased at least in proportion to the increase in TC, and in the lactescent sera a greater than normal fraction of total cholesterol was free. Phospholipid (PL) was increased whenever TC was increased but to a lesser degree; the ratios of $\mathrm{TC} / \mathrm{PL}$ were greater than normal in all sera with increased lipids and were greatest in the sera with the greatest concentrations of TC (Figure 3). Values of TC/PL were correlated on average with the degree of lactescence of the sera but the relationship was in- 
TABLE II

Data on sera of Category A, with total cholesterol greater than $350 \mathrm{mg}$ per $100 \mathrm{ml}$

\begin{tabular}{|c|c|c|c|c|c|c|c|c|c|c|c|}
\hline $\begin{array}{c}\text { Serum } \\
\text { no. }\end{array}$ & Patient & $\begin{array}{l}\text { Age and } \\
\text { sex }\end{array}$ & Date & TC* & PL* & TG* & $T L *$ & FC/TC & $\mathrm{TC} / \mathrm{PL}$ & TC/TG & Albumin \\
\hline \multicolumn{11}{|c|}{$m g / 100 m l$} & \multirow{2}{*}{$\begin{array}{c}\mathrm{g} / 100 \mathrm{ml} \\
4.0\end{array}$} \\
\hline \multicolumn{4}{|c|}{ Approx. normal values for young adults } & 179 & 226 & 100 & 580 & 0.25 & 0.79 & 1.8 & \\
\hline \multicolumn{12}{|c|}{ Group 1 (very lactescent) } \\
\hline $\begin{array}{l}1 \\
2 \\
3 \\
4 \\
5 \\
6 \\
7 \\
8 \\
\mathrm{Me}\end{array}$ & $\begin{array}{l}\text { J. H. } \\
\text { D. B. } \\
\text { S. S. } \\
\text { L. G. } \\
\text { W. T. } \\
\text { W. T. } \\
\text { C. D. } \\
\text { C. P. }\end{array}$ & $\begin{array}{rl}2 & M \\
2 & F \\
33 & M \\
29 & M \\
10 M \\
10 M \\
7 & F \\
6 & M\end{array}$ & $\begin{array}{r}11 / 15 / 54 \\
10 / 12 / 54 \\
2 / 15 / 55 \\
2 / 25 / 55 \\
7 / 5 / 57 \\
6 / 12 / 57 \\
2 / 15 / 56 \\
7 / 29 / 55\end{array}$ & $\begin{array}{r}677 \\
1,058 \\
1,522 \\
1,234 \\
878 \\
774 \\
1,174 \\
1,293 \\
1,112\end{array}$ & $\begin{array}{r}620 \\
1,064 \\
942 \\
785 \\
671 \\
650 \\
848 \\
968 \\
841\end{array}$ & $\begin{array}{l}3,820 \\
3,220 \\
3,210 \\
2,440 \\
2,103 \\
2,074 \\
2,377 \\
2,359 \\
2,788\end{array}$ & $\begin{array}{l}5,439 \\
5,817 \\
6,409 \\
5,063 \\
4,070 \\
3,872 \\
4,966 \\
5,253 \\
5,274\end{array}$ & $\begin{array}{l}0.30 \\
0.34 \\
0.29 \\
0.28 \\
0.30 \\
0.29 \\
0.29 \\
0.28 \\
0.30\end{array}$ & $\begin{array}{l}1.09 \\
0.99 \\
1.63 \\
1.57 \\
1.31 \\
1.19 \\
1.39 \\
1.34 \\
1.32\end{array}$ & $\begin{array}{l}0.2 \\
0.3 \\
0.5 \\
0.5 \\
0.4 \\
0.5 \\
0.5 \\
0.5 \\
0.4\end{array}$ & $\begin{array}{l}0.6 \\
0.4 \\
0.8 \\
0.6 \\
0.5 \\
0.5 \\
0.4 \\
0.9 \\
0.60\end{array}$ \\
\hline \multicolumn{12}{|c|}{ Group 2 (lactescent) } \\
\hline $\begin{array}{r}9 \\
10 \\
11 \\
12 \\
13 \\
14 \\
15 \\
16 \\
17 \\
18 \\
19 \\
\mathrm{Me}\end{array}$ & $\begin{array}{l}\text { R. B. } \\
\text { R. B. } \\
\text { J. S. } \\
\text { J. S. } \\
\text { F. G. } \\
\text { N. G. } \\
\text { N. G. } \\
\text { C. T. } \\
\text { C. T. } \\
\text { C. T. } \\
\text { G. W. }\end{array}$ & $\begin{array}{r}6 \mathrm{~F} \\
6 \mathrm{~F} \\
4 \mathrm{M} \\
4 \mathrm{M} \\
45 \mathrm{M} \\
45 \mathrm{~F} \\
45 \mathrm{~F} \\
36 \mathrm{M} \\
36 \mathrm{M} \\
36 \mathrm{M} \\
13 \mathrm{M}\end{array}$ & $\begin{array}{l}4 / 1 / 58 \\
4 / 7 / 58 \\
7 / 21 / 58 \\
7 / 24 / 58 \\
2 / 10 / 59 \\
3 / 11 / 58 \\
2 / 24 / 58 \\
7 / 22 / 57 \\
7 / 10 / 57 \\
7 / 20 / 57 \\
7 / 17 / 58\end{array}$ & $\begin{array}{l}698 \\
659 \\
693 \\
736 \\
659 \\
405 \\
402 \\
639 \\
628 \\
620 \\
868 \\
659\end{array}$ & $\begin{array}{l}\mathbf{6 4 1} \\
\mathbf{5 5 9} \\
\mathbf{5 5 2} \\
\mathbf{5 5 2} \\
\mathbf{6 3 3} \\
\mathbf{4 1 0} \\
396 \\
456 \\
469 \\
458 \\
619 \\
\mathbf{5 4 5}\end{array}$ & $\begin{array}{r}1,204 \\
1,151 \\
1,111 \\
950 \\
1,059 \\
739 \\
581 \\
825 \\
700 \\
694 \\
627 \\
882\end{array}$ & $\begin{array}{l}2,885 \\
2,687 \\
2,686 \\
2,595 \\
2,653 \\
1,746 \\
1,570 \\
2,233 \\
2,096 \\
2,075 \\
2,545 \\
2,403\end{array}$ & $\begin{array}{l}0.28 \\
0.29 \\
0.30 \\
0.29 \\
0.33 \\
0.30 \\
0.30 \\
0.28 \\
0.30 \\
0.28 \\
0.27 \\
0.29\end{array}$ & $\begin{array}{l}1.09 \\
1.18 \\
1.25 \\
1.33 \\
1.04 \\
0.99 \\
1.01 \\
1.40 \\
1.34 \\
1.35 \\
1.40 \\
1.21\end{array}$ & $\begin{array}{l}0.6 \\
0.6 \\
0.7 \\
0.7 \\
0.6 \\
0.6 \\
0.7 \\
0.8 \\
0.9 \\
0.9 \\
1.4 \\
0.8\end{array}$ & $\begin{array}{l}0.7 \\
0.8 \\
0.6 \\
0.6 \\
1.0 \\
2.2 \\
2.3 \\
0.8 \\
0.9 \\
0.9 \\
0.3 \\
0.97\end{array}$ \\
\hline \multicolumn{12}{|c|}{ Group 3 (slightly lactescent) } \\
\hline $\begin{array}{l}20 \\
21 \\
22 \\
23 \\
24 \\
25 \\
26 \\
27 \\
28 \\
29 \\
30 \\
31 \\
32 \\
33 \\
34 \\
35 \\
36 \\
37 \\
38 \\
\text { Mea }\end{array}$ & $\begin{array}{l}\text { W. G. } \\
\text { O. H. } \\
\text { K. R. } \\
\text { J. J. S. } \\
\text { E. W. } \\
\text { R. S. } \\
\text { R. S. } \\
\text { D. Z. } \\
\text { R. B. } \\
\text { M. K. } \\
\text { F. F. } \\
\text { M. H. } \\
\text { W. T. } \\
\text { M. D. } \\
\text { A. R. } \\
\text { O. C. } \\
\text { B. G. } \\
\text { K. R. } \\
\text { F. N. } \\
\text { n. }\end{array}$ & $\begin{array}{r}61 \mathrm{M} \\
41 \mathrm{M} \\
14 \mathrm{M} \\
9 \mathrm{M} \\
50 \mathrm{M} \\
5 \mathrm{M} \\
5 \mathrm{M} \\
19 \mathrm{M} \\
6 \mathrm{~F} \\
54 \mathrm{M} \\
30 \mathrm{~F} \\
27 \mathrm{~F} \\
10 \mathrm{M} \\
6 \mathrm{M} \\
7 \mathrm{M} \\
68 \mathrm{M} \\
16 \mathrm{~F} \\
14 \mathrm{M} \\
65 \mathrm{M}\end{array}$ & $\begin{array}{r}2 / 15 / 56 \\
2 / 6 / 55 \\
10 / 3 / 57 \\
9 / 9 / 58 \\
2 / 25 / 55 \\
3 / 12 / 57 \\
2 / 28 / 55 \\
7 / 10 / 56 \\
5 / 12 / 58 \\
2 / 15 / 56 \\
11 / 25 / 54 \\
9 / 16 / 58 \\
3 / 1 / 58 \\
3 / 13 / 56 \\
1 / 7 / 58 \\
2 / 24 / 58 \\
8 / 3 / 54 \\
9 / 19 / 57 \\
1 / 27 / 59\end{array}$ & $\begin{array}{r}755 \\
588 \\
703 \\
427 \\
857 \\
710 \\
682 \\
369 \\
502 \\
556 \\
471 \\
430 \\
409 \\
566 \\
\mathbf{5 9 0} \\
378 \\
\mathbf{3 5 4} \\
1,053 \\
625 \\
\mathbf{5 7 4}\end{array}$ & $\begin{array}{l}523 \\
497 \\
537 \\
379 \\
691 \\
602 \\
592 \\
353 \\
462 \\
475 \\
419 \\
404 \\
347 \\
481 \\
477 \\
377 \\
354 \\
700 \\
479 \\
475\end{array}$ & $\begin{array}{l}583 \\
570 \\
551 \\
485 \\
480 \\
432 \\
390 \\
427 \\
414 \\
409 \\
400 \\
386 \\
370 \\
348 \\
331 \\
324 \\
320 \\
294 \\
266 \\
409\end{array}$ & $\begin{array}{l}2,365 \\
1,955 \\
2,140 \\
1,494 \\
2,443 \\
2,106 \\
2,021 \\
1,330 \\
1,630 \\
1,722 \\
1,424 \\
1,419 \\
1,335 \\
1,616 \\
1,695 \\
1,269 \\
1,208 \\
2,591 \\
1,508 \\
1,734\end{array}$ & $\begin{array}{l}0.29 \\
0.25 \\
0.27 \\
0.30 \\
0.29 \\
0.25 \\
0.23 \\
0.28 \\
0.26 \\
0.28 \\
0.27 \\
0.32 \\
0.25 \\
0.26 \\
0.26 \\
0.26 \\
0.25 \\
0.24 \\
0.27 \\
0.27\end{array}$ & $\begin{array}{l}1.44 \\
1.18 \\
1.31 \\
1.12 \\
1.24 \\
1.18 \\
1.21 \\
1.04 \\
1.09 \\
1.17 \\
1.12 \\
1.06 \\
1.18 \\
1.18 \\
1.24 \\
1.00 \\
1.00 \\
1.50 \\
1.30 \\
1.19\end{array}$ & $\begin{array}{l}1.3 \\
1.0 \\
1.3 \\
0.9 \\
1.8 \\
1.7 \\
1.6 \\
0.9 \\
1.2 \\
1.4 \\
1.2 \\
1.1 \\
1.1 \\
1.6 \\
1.8 \\
1.2 \\
1.1 \\
3.6 \\
2.4 \\
1.5\end{array}$ & $\begin{array}{l}0.8 \\
1.1 \\
0.7 \\
1.1 \\
0.9 \\
0.8 \\
0.6 \\
1.6 \\
1.0 \\
1.6 \\
1.0 \\
1.3 \\
1.5 \\
2.0 \\
0.8 \\
1.2 \\
1.2 \\
0.8 \\
1.0 \\
1.13\end{array}$ \\
\hline \multicolumn{12}{|c|}{ Group 4 (clear) } \\
\hline $\begin{array}{l}39 \\
40 \\
41 \\
42 \\
43 \\
44 \\
45 \\
46 \\
47 \\
48 \\
49 \\
50 \\
51 \\
52 \\
53 \\
54 \\
55 \\
56 \\
57 \\
58 \\
\text { Mea }\end{array}$ & $\begin{array}{l}\text { J. W. } \\
\text { W. T. } \\
\text { J. M. } \\
\text { S. S. } \\
\text { S. S. } \\
\text { L. N. } \\
\text { E. G. } \\
\text { D. P. } \\
\text { F. F. } \\
\text { E. T. } \\
\text { E. T. } \\
\text { M. E. H. } \\
\text { M. C. } \\
\text { S. J. } \\
\text { A. R. } \\
\text { A. R. } \\
\text { C. T. } \\
\text { H. B. } \\
\text { O. H. } \\
\text { L. N. } \\
\text { in }\end{array}$ & $\begin{array}{rl}3 & M \\
11 & M \\
4 & F \\
35 & M \\
34 & M \\
21 & F \\
44 & M \\
3 & M \\
32 & F \\
9 & M \\
9 & M \\
5 & F \\
14 & F \\
15 & M \\
4 & M \\
4 & M \\
36 & M \\
50 & M \\
41 & M \\
21 & F\end{array}$ & $\begin{array}{r}2 / 24 / 54 \\
2 / 26 / 58 \\
3 / 21 / 57 \\
3 / 25 / 57 \\
2 / 15 / 56 \\
6 / 27 / 55 \\
2 / 10 / 54 \\
4 / 5 / 57 \\
5 / 23 / 56 \\
2 / 4 / 54 \\
1 / 25 / 54 \\
4 / 9 / 57 \\
8 / 22 / 56 \\
6 / 26 / 58 \\
5 / 18 / 55 \\
4 / 20 / 55 \\
10 / 23 / 57 \\
10 / 29 / 58 \\
7 / 3 / 56 \\
8 / 16 / 55\end{array}$ & $\begin{array}{l}364 \\
459 \\
590 \\
379 \\
604 \\
464 \\
438 \\
703 \\
468 \\
469 \\
518 \\
678 \\
676 \\
373 \\
533 \\
586 \\
357 \\
432 \\
351 \\
434 \\
490\end{array}$ & $\begin{array}{l}320 \\
366 \\
464 \\
399 \\
457 \\
368 \\
352 \\
514 \\
384 \\
394 \\
391 \\
499 \\
538 \\
325 \\
493 \\
479 \\
310 \\
383 \\
359 \\
378 \\
404\end{array}$ & $\begin{aligned} 218 \\
205 \\
199 \\
197 \\
189 \\
189 \\
186 \\
174 \\
172 \\
170 \\
145 \\
169 \\
158 \\
140 \\
160 \\
120 \\
141 \\
132 \\
75 \\
36 \\
158\end{aligned}$ & $\begin{array}{r}1,083 \\
1,270 \\
1,554 \\
1,171 \\
1,546 \\
1,245 \\
1,202 \\
1,747 \\
1,269 \\
1,285 \\
1,325 \\
1,683 \\
1,703 \\
1,030 \\
1,476 \\
1,500 \\
992 \\
1,165 \\
971 \\
1,072 \\
1,302\end{array}$ & $\begin{array}{l}0.27 \\
0.23 \\
0.25 \\
0.24 \\
0.28 \\
0.28 \\
0.24 \\
0.24 \\
0.23 \\
0.21 \\
0.23 \\
0.27 \\
0.28 \\
0.24 \\
0.20 \\
0.21 \\
0.24 \\
0.26 \\
0.22 \\
0.24 \\
0.25\end{array}$ & $\begin{array}{l}1.14 \\
1.26 \\
1.27 \\
0.95 \\
1.32 \\
1.25 \\
1.24 \\
1.37 \\
1.22 \\
1.19 \\
1.32 \\
1.36 \\
1.25 \\
1.15 \\
1.08 \\
1.22 \\
1.15 \\
1.13 \\
0.98 \\
1.15 \\
1.20\end{array}$ & $\begin{array}{r}1.7 \\
2.2 \\
3.0 \\
1.9 \\
3.2 \\
2.4 \\
2.4 \\
4.0 \\
2.7 \\
2.8 \\
3.6 \\
4.0 \\
4.3 \\
2.7 \\
3.3 \\
4.0 \\
2.5 \\
3.3 \\
4.7 \\
12.5 \\
3.7\end{array}$ & $\begin{array}{l}2.8 \\
1.2 \\
1.9 \\
2.5 \\
2.3 \\
1.0 \\
1.5 \\
0.9 \\
1.7 \\
1.2 \\
1.6 \\
1.2 \\
0.6 \\
2.8 \\
1.6 \\
2.0 \\
2.7 \\
1.3 \\
2.3 \\
1.2 \\
1.69\end{array}$ \\
\hline
\end{tabular}

* $\mathrm{TC}=$ total cholesterol $; \mathrm{PL}=$ phospholipid $; \mathrm{TG}=$ triglyceride $; \mathrm{TL}=$ total lipid. 
TABLE III

Data on sera of Category B, with total cholesterol less than $300 \mathrm{mg}$ per $100 \mathrm{ml}$ *

\begin{tabular}{|c|c|c|c|c|c|c|c|c|c|c|c|}
\hline $\begin{array}{c}\text { Serum } \\
\text { no. }\end{array}$ & Patient & $\begin{array}{c}\text { Age and } \\
\text { sex }\end{array}$ & Date & TC & PL & TG & TL & $\mathrm{FC} / \mathrm{TC}$ & $\mathrm{TC} / \mathrm{PL}$ & $\mathrm{TC} / \mathrm{TG}$ & Albumin \\
\hline \multicolumn{12}{|c|}{$\begin{array}{l}m g / 100 m l \\
\text { Group } 5\end{array}$} \\
\hline $\begin{array}{l}59 \\
60 \\
61 \\
62 \\
63 \\
64 \\
65 \\
66 \\
67 \\
68\end{array}$ & $\begin{array}{l}\text { R. T. } \\
\text { M. F. } \\
\text { M. F. } \\
\text { W. T. } \\
\text { M. C. } \\
\text { M. C. } \\
\text { C. R. } \\
\text { E. T. } \\
\text { C. D. } \\
\text { R. Q. }\end{array}$ & $\begin{array}{l}34 \mathrm{M} \\
17 \mathrm{~F} \\
17 \mathrm{~F} \\
10 \mathrm{M} \\
14 \mathrm{~F} \\
14 \mathrm{~F} \\
30 \mathrm{M} \\
9 \mathrm{M} \\
7 \mathrm{~F} \\
3 \mathrm{M}\end{array}$ & $\begin{array}{r}5 / 19 / 58 \\
5 / 19 / 58 \\
5 / 27 / 58 \\
10 / 16 / 57 \\
3 / 8 / 57 \\
4 / 30 / 57 \\
1 / 9 / 57 \\
5 / 8 / 54 \\
7 / 11 / 56 \\
12 / 18 / 56\end{array}$ & $\begin{array}{l}266 \\
269 \\
193 \\
189 \\
285 \\
263 \\
232 \\
209 \\
286 \\
292\end{array}$ & $\begin{array}{l}330 \\
249 \\
225 \\
219 \\
268 \\
260 \\
222 \\
214 \\
288 \\
282\end{array}$ & $\begin{array}{r}495 \\
106 \\
161 \\
141 \\
142 \\
110 \\
104 \\
107 \\
95 \\
70\end{array}$ & $\begin{array}{r}1,220 \\
761 \\
676 \\
645 \\
836 \\
766 \\
672 \\
668 \\
817 \\
795\end{array}$ & $\begin{array}{l}0.29 \\
0.25 \\
0.26 \\
0.25 \\
0.27 \\
0.26 \\
0.28 \\
0.27 \\
0.24 \\
0.24\end{array}$ & $\begin{array}{l}0.81 \\
1.1 \\
0.86 \\
0.86 \\
1.1 \\
1.0 \\
1.0 \\
0.98 \\
0.99 \\
1.0\end{array}$ & $\begin{array}{l}0.5 \\
2.5 \\
1.2 \\
1.3 \\
2.0 \\
2.4 \\
2.2 \\
2.0 \\
3.0 \\
4.2\end{array}$ & $\begin{array}{l}2.8 \\
2.4 \\
2.3 \\
3.1 \\
2.4 \\
2.5 \\
2.6 \\
2.9 \\
2.2 \\
3.2\end{array}$ \\
\hline \multicolumn{2}{|c|}{ Mean } & & & 247 & 257 & 159 & 792 & 0.26 & 0.97 & 2.2 & 2.71 \\
\hline \multicolumn{12}{|c|}{ Group 6} \\
\hline $\begin{array}{l}69 \\
70 \\
71 \\
72 \\
73 \\
74 \\
75 \\
76 \\
77 \\
78 \\
79 \\
80 \\
81 \\
82\end{array}$ & $\begin{array}{l}\text { R. K. } \\
\text { R. K. } \\
\text { D. B. } \\
\text { L. G. } \\
\text { C. J. } \\
\text { K. R. } \\
\text { E. W. } \\
\text { E. K. } \\
\text { J. W. } \\
\text { R. S. } \\
\text { R. Q. } \\
\text { A. R. } \\
\text { E. G. } \\
\text { E. G. }\end{array}$ & $\begin{array}{rl}7 & \mathrm{M} \\
7 \mathrm{M} \\
3 \mathrm{~F} \\
30 \mathrm{M} \\
2 \mathrm{~F} \\
14 \mathrm{M} \\
51 \mathrm{M} \\
2 \mathrm{~F} \\
30 \mathrm{M} \\
4 \mathrm{M} \\
2 \mathrm{M} \\
5 \mathrm{M} \\
46 \mathrm{M} \\
46 \mathrm{M}\end{array}$ & $\begin{array}{r}5 / 23 / 56 \\
8 / 15 / 56 \\
10 / 12 / 55 \\
7 / 11 / 56 \\
2 / 2 / 55 \\
12 / 9 / 57 \\
7 / 25 / 56 \\
6 / 20 / 56 \\
7 / 11 / 55 \\
6 / 6 / 56 \\
9 / 7 / 55 \\
2 / 26 / 56 \\
5 / 29 / 56 \\
7 / 11 / 56\end{array}$ & $\begin{array}{l}183 \\
178 \\
241 \\
218 \\
174 \\
184 \\
229 \\
178 \\
262 \\
188 \\
193 \\
172 \\
189 \\
222\end{array}$ & $\begin{array}{l}247 \\
220 \\
231 \\
220 \\
214 \\
223 \\
213 \\
211 \\
254 \\
219 \\
194 \\
190 \\
250 \\
252\end{array}$ & $\begin{array}{r}267 \\
204 \\
192 \\
190 \\
160 \\
144 \\
105 \\
92 \\
86 \\
83 \\
75 \\
72 \\
76 \\
57\end{array}$ & $\begin{array}{l}793 \\
692 \\
785 \\
740 \\
638 \\
644 \\
669 \\
571 \\
734 \\
584 \\
568 \\
522 \\
607 \\
649\end{array}$ & $\begin{array}{l}0.23 \\
0.26 \\
0.26 \\
0.25 \\
0.24 \\
0.25 \\
0.21 \\
0.25 \\
0.26 \\
0.27 \\
0.19 \\
0.21 \\
0.27 \\
0.22\end{array}$ & $\begin{array}{l}0.74 \\
0.81 \\
0.92 \\
0.99 \\
0.81 \\
0.83 \\
1.1 \\
0.84 \\
1.0 \\
0.86 \\
1.0 \\
0.91 \\
0.76 \\
0.88\end{array}$ & $\begin{array}{l}0.7 \\
0.9 \\
1.2 \\
1.1 \\
1.1 \\
1.3 \\
2.2 \\
1.9 \\
3.0 \\
2.3 \\
2.6 \\
2.4 \\
2.5 \\
3.9\end{array}$ & $\begin{array}{l}3.5 \\
3.3 \\
3.4 \\
3.9 \\
4.1 \\
3.8 \\
4.0 \\
3.8 \\
3.9 \\
3.5 \\
4.0 \\
3.8 \\
3.3 \\
3.2\end{array}$ \\
\hline \multicolumn{2}{|c|}{ Mean } & & & 202 & 221 & 125 & 652 & 0.24 & 0.91 & 1.9 & 3.74 \\
\hline
\end{tabular}

* For abbreviations, see footnote to Table II.

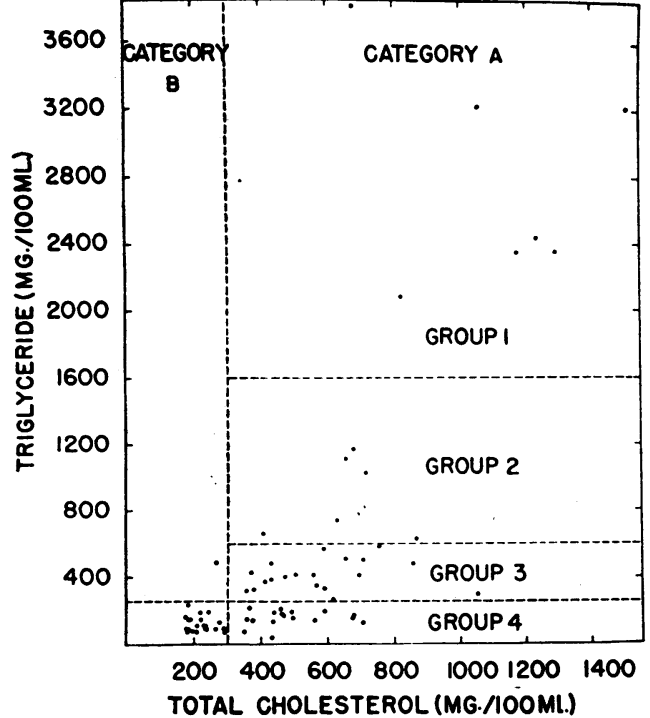

Fig. 1. RELAtionship BetweEn SERUM tRIGLYCERIDE AND SERUM TOTAL CHOLESTEROL. The various categories and groups of sera are indicated. consistent among the individual sera. Lactescence was related to the ratio of total lipid (TL) to PL, as noted by Ahrens and Kunkel (21), and less regularly to TL/TC. Lactescence also was related to the level of triglyceride, which explains in part the relationship of lactescence to TL/PL and to $\mathrm{TL} / \mathrm{TC}$.

While TC and PL were clearly in excess of normal in all sera of Groups 1 through 4 with some similar concentrations in each group, triglyceride (TG) ranged from very high levels in Group 1 to approximately normal levels in Group 4, with distinctly different ranges of values in the different groups. Ratios of TC/TG varied from a fraction of normal in Group 1 to several times normal in Group 4, and, among sera with TC concentrations in the vicinity of 700 , concentrations of TG ranged all the way from 120 to $3,820 \mathrm{mg}$ per $100 \mathrm{ml}$. All of the lipids increased together on average but the relation- 


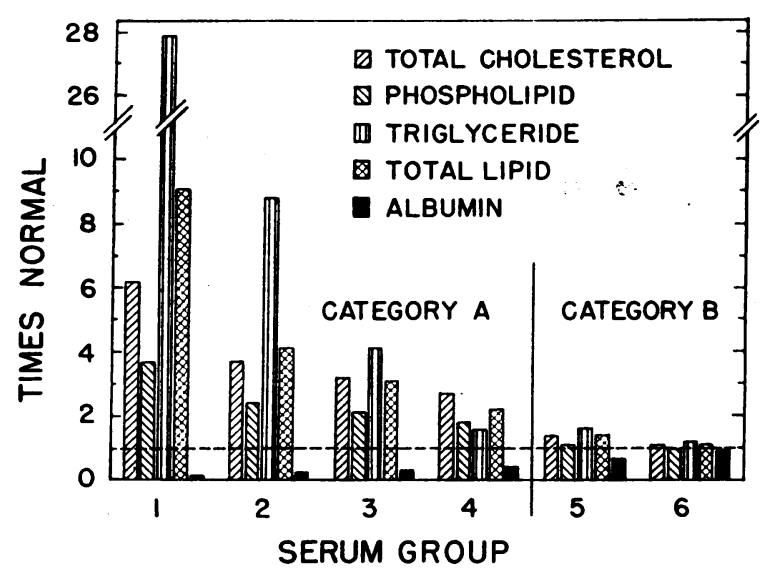

Fig. 2. MEAN CONCENTRATIONS OF Lipids AND ALbUMIN IN SERA OF THE VARIOUS GROUPS IN RELATION TO NORMAL CONCENTRATIONS. The normal values are shown in Table II.

ship between TC and TG was very irregular as may be seen in Figure 1. Thus there were qualitative as well as quantitative differences in the lipids in the different sera. These qualitative differences were related to differences in lipoprotein pattern which are discussed below.

\section{Relationship between serum lipids and serum albumin}

The concentrations of the various classes of lipids in the sera are shown in relation to the

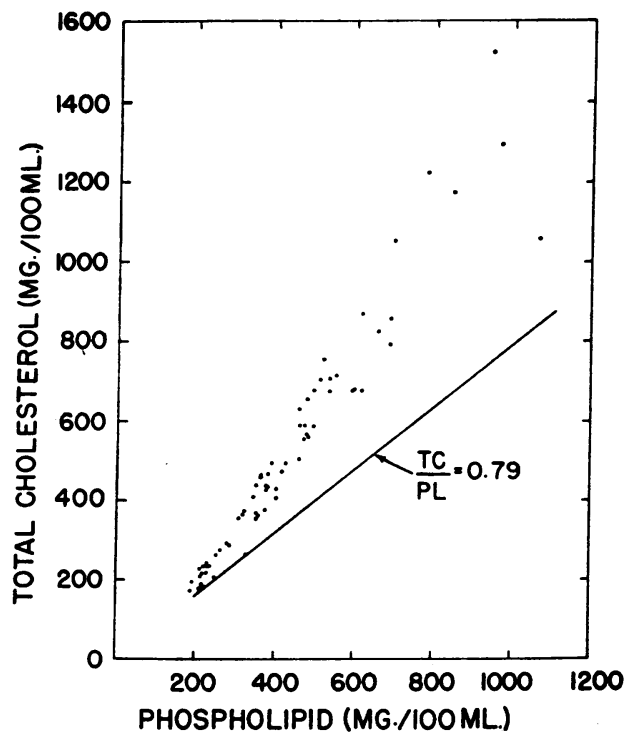

FIG. 3. RELATIONSHIP BETWEEN SERUM TOTAL CHOLESTEROL AND SERUM PHOSPHOLIPID. The normal ratio of TC/PL is shown.

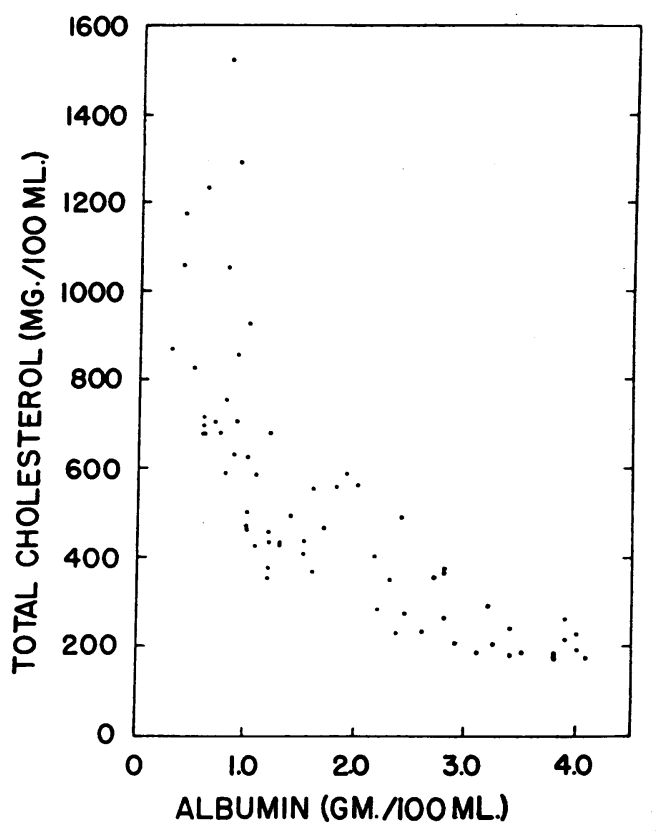

Fig. 4. Relation OF SERUM tOtal Cholesterol to SERUM ALBUMIN.

corresponding concentrations of serum albumin in Figures 4 through 6. It is evident that inverse correlations existed in each case. The relationships were approximately hyperbolic, with the lipids, particularly triglyceride, increasing sharply as albumin decreased below levels of about $1 \mathrm{~g}$ per $100 \mathrm{ml}$. Reciprocals of total cholesterol and of phospholipid concentrations were associated linearly with albumin concentrations with correlation

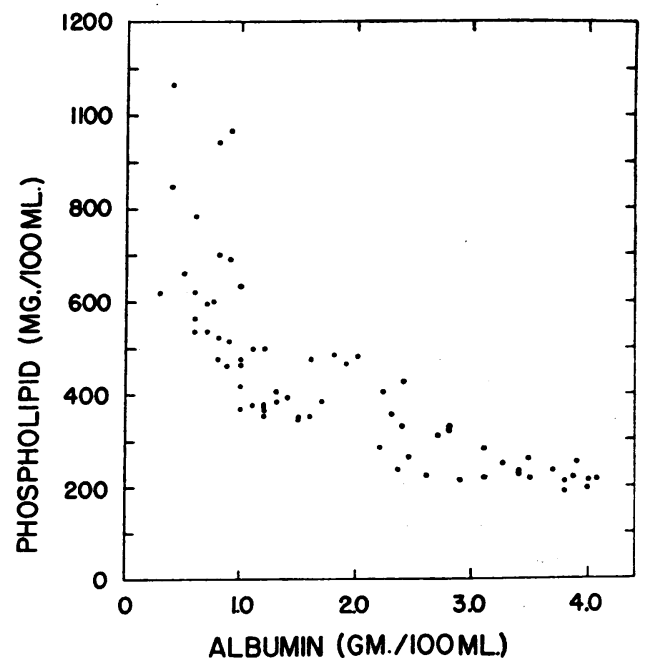

Fig. 5. RELATION OF SERUM PHOSPHOLIPID TO SERUM ALBUMIN. 


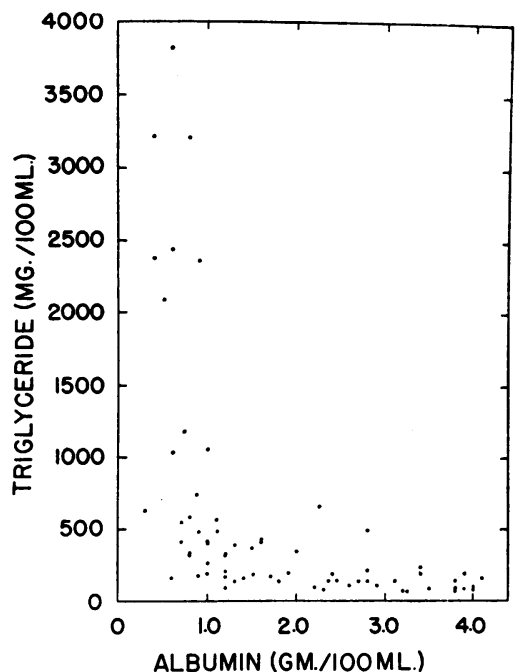

Fig. 6. RELATION OF SERUM TRIGLYCERIDE TO SERUM ALBUMIN.

coefficients $(R)$ of at least +0.90 . The relationship between triglyceride and albumin was less regular, and more suggestive of the importance of a critical concentration of albumin. The relationship between total lipid and albumin rèsembled in form and regularity the relationship between TC or PL and albumin more closely than it resembled that between TG and albumin.

\section{Serum lipoproteins}

The lipoprotein fraction which was isolated in the top portion of the tubes by centrifugation of the sera at a density of 1.019 included all of the lactescent material of the sera. The lipoproteins which were subsequently separated at D 1.063 were clear and often yellow, and those separated at D 1.21 were clear and only slightly colored. Results of analyses of the lipoprotein fractions from sera of each of the four groups of Category $A$ are shown in Table IV. The mean results are expressed as multiples of normal values (11, 12) in Figure 7.

$D<1.019$ lipoproteins. Concentrations of the very low density lipoproteins were greatly increased in the lactescent sera of Group 1, moderately increased in sera of Groups 2 and 3 , and only slightly above normal in the clear sera of Group 4.

This fraction varied from group to group in composition as well as in quantity. It contained most of the excess triglyceride of the sera, but its cholesterol (in all groups) and phospholipid (in all but the first group) were increased at least in proportion to the increase in triglyceride. $\mathrm{Ra}$ tios of TC/PL for the fraction were greater than normal in all serum groups, greatest in Group 1 and least in Group 4. The quantity of protein in the fraction, like that of the lipids, was greatest in Group 1 and progressively less in the other groups. Concentrations of protein in Groups 2 through 4 are not presented because of some irregularly large values. The patterns of lipoproteins (according to density) within this heterogeneous fraction and the composition of different portions of the fraction were not investigated extensively. Results of a subfractionation are discussed in a later section.

D 1.019-1.063 lipoproteins. In contrast to the trend of the $\mathrm{D}<1.019$ lipoproteins described above, there was a stepwise increase in quantity of the D 1.019-1.063 fraction from Group 1 to Group 4. This medium-density fraction was near normal concentration in Group 1, irregularly in-

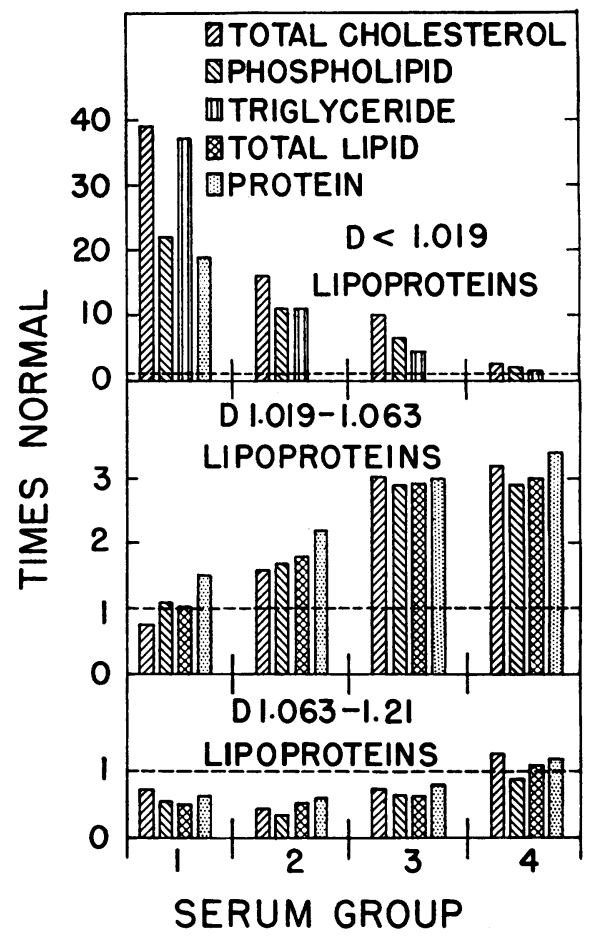

Fig. 7. MEAN CONCENTRATIONS OF Lipids AND PROTEIN OF THREE LIPOPROTEIN FRACTIONS IN SERA OF VARIOUS GROUPS IN RELATION TO NORMAL CONCENTRATIONS. The normal values are shown in Table IV. 
TABLE IV

Data on lipoprotein fractions of four groups of sera with increased lipids *

\begin{tabular}{|c|c|c|c|c|c|c|c|c|c|c|c|c|c|c|c|}
\hline \multirow{3}{*}{$\begin{array}{c}\text { Serum } \\
\text { no. }\end{array}$} & \multicolumn{15}{|c|}{ Lipoprotein fraction } \\
\hline & \multicolumn{5}{|c|}{$\mathrm{D}<1.019$} & \multicolumn{5}{|c|}{ D 1.019-1.063 } & \multicolumn{5}{|c|}{ D 1.063-1.21 } \\
\hline & TC & PL & TG & $\mathrm{FC} / \mathrm{TC}$ & $\mathrm{TC} / \mathrm{PL}$ & TL & TC & PL & $\mathbf{P}$ & TC/PL & TL & TC & PL & $\mathbf{P}$ & $\mathrm{TC} / \mathrm{PL}$ \\
\hline & \multicolumn{5}{|c|}{$\mathrm{mg} / 100 \mathrm{ml}$ of serum } & \multicolumn{5}{|c|}{$\mathrm{mg} / 100 \mathrm{ml}$ of serum } & \multicolumn{5}{|c|}{$\mathrm{mg} / 100 \mathrm{ml}$ of serum } \\
\hline values. & $\ldots 23$ & 28 & 78 & 0.37 & 0.82 & 265 & 103 & 74 & 70 & 1.39 & 190 & 49 & 101 & 170 & 0.48 \\
\hline \multicolumn{16}{|c|}{ Group 1} \\
\hline $\begin{array}{l}1 \\
2 \\
3 \\
4 \\
5 \mathrm{~b} \ddagger \\
5 \mathrm{a} \\
5\end{array}$ & $\begin{array}{r}609 \\
907 \\
1,247 \\
1,023 \\
624 \\
655 \\
778\end{array}$ & $\begin{array}{l}482 \\
791 \\
699 \\
591 \\
527 \\
535 \\
527\end{array}$ & $\begin{array}{c}(3,700) \dagger \\
(3,100) \\
(3,100) \\
(2,300) \\
2,485 \\
2,422 \\
2,021\end{array}$ & $\begin{array}{l}0.37 \\
0.35 \\
0.31\end{array}$ & $\begin{array}{l}1.27 \\
1.15 \\
1.79 \\
1.73 \\
1.18 \\
1.22 \\
1.47\end{array}$ & $\begin{array}{l}265 \\
265 \\
281\end{array}$ & $\begin{array}{l}52 \\
90 \\
98 \\
78 \\
63 \\
54 \\
77\end{array}$ & $\begin{array}{l}86 \\
87 \\
99 \\
81 \\
75 \\
62 \\
67\end{array}$ & $\begin{array}{r}96 \\
109 \\
96 \\
53 \\
95 \\
128\end{array}$ & $\begin{array}{l}0.61 \\
1.03 \\
0.99 \\
0.96 \\
0.84 \\
0.87 \\
1.15\end{array}$ & $\begin{array}{r}104 \\
69 \\
99\end{array}$ & $\begin{array}{r}16 \\
82 \\
46 \\
21 \\
19 \\
9 \\
17\end{array}$ & $\begin{array}{l}85 \\
55 \\
47 \\
17 \\
37\end{array}$ & $\begin{array}{r}121 \\
120 \\
91 \\
56 \\
95\end{array}$ & $\begin{array}{l}0.54 \\
0.38 \\
0.40 \\
0.41 \\
0.46\end{array}$ \\
\hline Mean & 894 & 619 & 2,901 & 0.34 & 1.45 & 270 & 77 & 84 & 103 & 0.91 & 91 & 36 & 58 & 107 & 0.45 \\
\hline \multicolumn{16}{|c|}{ Group 2} \\
\hline $\begin{array}{r}9 \\
11 \\
12 \\
13 \\
14 \\
15 \\
16 \\
18\end{array}$ & $\begin{array}{l}386 \\
412 \\
406 \\
404 \\
244 \\
237 \\
507 \\
388\end{array}$ & $\begin{array}{l}361 \\
336 \\
278 \\
379 \\
222 \\
222 \\
341 \\
289\end{array}$ & $\begin{array}{r}1,047 \\
1,013 \\
876 \\
903 \\
590 \\
522 \\
799 \\
613\end{array}$ & $\begin{array}{l}0.34 \\
0.34 \\
0.31 \\
0.35 \\
0.35 \\
0.35 \\
0.31 \\
0.28\end{array}$ & $\begin{array}{l}1.07 \\
1.22 \\
1.46 \\
1.07 \\
1.10 \\
1.07 \\
1.49 \\
1.34\end{array}$ & $\begin{array}{l}503 \\
651 \\
548 \\
685 \\
309 \\
313 \\
322 \\
280\end{array}$ & $\begin{array}{r}184 \\
216 \\
203 \\
212 \\
96 \\
115 \\
103 \\
76\end{array}$ & $\begin{array}{r}131 \\
164 \\
142 \\
190 \\
80 \\
87 \\
83 \\
67\end{array}$ & $\begin{array}{r}170 \\
219 \\
198 \\
187 \\
134 \\
125 \\
61 \\
82\end{array}$ & $\begin{array}{l}1.40 \\
1.32 \\
1.43 \\
1.11 \\
1.20 \\
1.32 \\
1.24 \\
1.13\end{array}$ & $\begin{array}{r}165 \\
53 \\
67 \\
80 \\
119 \\
71 \\
116 \\
104\end{array}$ & $\begin{array}{r}32 \\
9 \\
11 \\
12 \\
28 \\
13 \\
24 \\
20\end{array}$ & $\begin{array}{l}51 \\
22 \\
22 \\
30 \\
48 \\
32 \\
47 \\
32\end{array}$ & $\begin{array}{r}136 \\
31 \\
65 \\
51 \\
146 \\
89 \\
119 \\
96\end{array}$ & $\begin{array}{l}0.63 \\
0.41 \\
0.50 \\
0.40 \\
0.58 \\
0.41 \\
0.51 \\
0.63\end{array}$ \\
\hline Mean & 377 & 317 & 831 & 0.33 & 1.20 & 480 & 160 & 127 & 153 & 1.27 & 102 & 19 & 37 & 92 & 0.51 \\
\hline \multicolumn{16}{|c|}{ Group 3} \\
\hline $\begin{array}{l}21 \\
22 \\
24 \\
25 \\
26 \\
28 \\
30 \\
35\end{array}$ & $\begin{array}{l}326 \\
378 \\
210 \\
132 \\
234 \\
133 \\
208 \\
100\end{array}$ & $\begin{array}{l}236 \\
291 \\
153 \\
119 \\
202 \\
144 \\
156 \\
120\end{array}$ & $\begin{array}{l}466 \\
238\end{array}$ & $\begin{array}{l}0.27 \\
0.31\end{array}$ & $\begin{array}{l}1.22 \\
1.30 \\
1.37 \\
1.11 \\
1.16 \\
0.92 \\
1.33 \\
0.83\end{array}$ & $\begin{array}{r}563 \\
1,260 \\
727\end{array}$ & $\begin{array}{l}229 \\
199 \\
604 \\
486 \\
333 \\
306 \\
201 \\
207\end{array}$ & $\begin{array}{l}184 \\
148 \\
420 \\
333 \\
232 \\
201 \\
144 \\
141\end{array}$ & $\begin{array}{l}177 \\
167 \\
351 \\
347 \\
221 \\
198 \\
135 \\
175\end{array}$ & $\begin{array}{l}1.24 \\
1.34 \\
1.44 \\
1.40 \\
1.43 \\
1.52 \\
1.40 \\
1.62\end{array}$ & 104 & $\begin{array}{l}54 \\
23 \\
47 \\
21\end{array}$ & $\begin{array}{l}60 \\
39 \\
82 \\
\\
99 \\
70\end{array}$ & $\begin{array}{r}107 \\
97 \\
157 \\
\\
195 \\
141\end{array}$ & $\begin{array}{l}0.55 \\
0.67 \\
0.70 \\
\\
0.55 \\
0.33\end{array}$ \\
\hline Mean & 220 & 180 & 334 & 0.33 & 1.16 & 764 & 308 & 217 & 212 & 1.43 & 119 & 37 & 66 & 137 & 0.54 \\
\hline \multicolumn{16}{|c|}{ Group 4} \\
\hline $\begin{array}{l}40 \\
41 \\
42 a \\
46 \\
50 \\
52 a \\
53 \\
54 \\
55\end{array}$ & $\begin{array}{r}72 \\
68 \\
23 \\
48 \\
64 \\
115 \\
40 \\
60 \\
61\end{array}$ & $\begin{array}{r}62 \\
57 \\
28 \\
49 \\
62 \\
104 \\
35 \\
48 \\
65\end{array}$ & $\begin{array}{r}91 \\
94 \\
86 \\
109 \\
125 \\
148\end{array}$ & $\begin{array}{l}0.26 \\
0.28 \\
0.35 \\
0.29 \\
0.31 \\
0.24\end{array}$ & $\begin{array}{l}1.16 \\
1.19 \\
0.82 \\
0.98 \\
1.03 \\
1.11 \\
1.14 \\
1.25 \\
0.94\end{array}$ & $\begin{array}{r}687 \\
1,000 \\
535 \\
1,236 \\
1,295 \\
342\end{array}$ & $\begin{array}{l}282 \\
415 \\
219 \\
541 \\
520 \\
135 \\
346 \\
382 \\
185\end{array}$ & $\begin{array}{r}183 \\
270 \\
146 \\
333 \\
343 \\
96 \\
255 \\
251 \\
122\end{array}$ & $\begin{array}{l}213 \\
308 \\
200 \\
376 \\
347 \\
107 \\
181 \\
228 \\
156\end{array}$ & $\begin{array}{l}1.49 \\
1.57 \\
1.50 \\
1.62 \\
1.53 \\
1.41 \\
1.36 \\
1.52 \\
1.51\end{array}$ & $\begin{array}{l}161 \\
320 \\
226 \\
268 \\
155 \\
128 \\
\\
139\end{array}$ & $\begin{array}{r}48 \\
102 \\
68 \\
97 \\
49 \\
26 \\
81 \\
85 \\
30\end{array}$ & $\begin{array}{r}62 \\
125 \\
105 \\
102 \\
76 \\
57 \\
175 \\
137 \\
55\end{array}$ & $\begin{array}{l}182 \\
307 \\
222 \\
226 \\
164 \\
139 \\
288 \\
275 \\
155\end{array}$ & $\begin{array}{l}0.79 \\
0.82 \\
0.64 \\
0.95 \\
0.64 \\
0.46 \\
0.46 \\
0.62 \\
0.55\end{array}$ \\
\hline Mean & 63 & 59 & 114 & 0.29 & 1.05 & 793 & 332 & 218 & 239 & 1.51 & 200 & 63 & 92 & 210 & 0.67 \\
\hline
\end{tabular}

* For abbreviations, see footnote to Table II.

t The values in parentheses are approximations based on serum triglyceride values.

$¥$ The addition of a letter to a serum number indicates a different but similar serum from the same patient. The $T L$ values here are calculated as milligrams of dichromate reduced divided by 17.7 .

creased in Group 2, and more substantially in- ues in Group 1 to greater than normal values in creased in Groups 3 and 4.

Group 4. Concentrations of total lipid instead of

The composition of this fraction varied. Ra- triglyceride of this and the $\mathrm{D} 1.063-1.21$ fractios of TC/PL ranged from less than normal val- tions are presented because of the large errors 
that may occur in calculating values of the relatively small $\mathrm{TG}$ component by difference. In cases of lactescent sera, it appeared that TG was increased relative to the other lipids of these fractions.

$D$ 1.063-1.21 lipoproteins. The high density lipoproteins were below normal in Groups 1, 2 and 3 , and above normal on average in Group 4 . Ratios of TC/PL in the fraction were greater than normal, particularly in Group 4. The high cholesterol values in a few of the sera of Group 4 suggest the possibility of incomplete separation of lipoproteins of lower density.

$D>1.21$ "lipid phosphorus." The quantity of ethanol-acetone soluble phosphorus remaining in the infranatant solution after centrifugation of the sera at D 1.21 varied considerably within each group, with no consistent difference from one group to another. The values in terms of phospholipid $(\mathrm{P} \times 25)$ ranged from 5 to $25 \mathrm{mg}$ per $100 \mathrm{ml}$ of serum with a mean of $15 \mathrm{mg}$ per 100 $\mathrm{ml}$, compared with a normal range of 15 to 27 $\mathrm{mg}$ per $100 \mathrm{ml}$ (11). The infranatant solution in the few cases analyzed was found to contain less than $3 \mathrm{mg}$ of cholesterol per $100 \mathrm{ml}$ of serum.

Summarizing the principal lipoprotein alterations in the different groups of sera with increased lipids, the lipoproteins of $\mathrm{D}<1.019$ were excessive in Group 1, both the $\mathrm{D}<1.019$ and the D 1.019-1.063 fractions were moderately increased in Groups 2 and 3, and principally the D 1.019-1.063 fraction was increased in Group 4. The $\mathrm{D}$ 1.063-1.21 fraction was diminished in Groups 1 through 3. It is evident that the previously discussed differences in serum triglyceride and in TC/TG (and also in TC/PL and PL/ $\mathrm{TL}$ ) in the different groups of sera were related to these differences in pattern of lipoproteins.

Different patterns of lipoproteins were also observed among the sera with slightly increased lipids (listed in Table III), as might be expected from the differences in TG levels and TC/TG ratios. The very low density lipoproteins were considerably above normal in serum no. 59. In most of the other sera, however, the lipoprotein abnormalities were not impressive.

Very low density lipoproteins and lactescence. The $\mathrm{D}<1.019$ lipoprotein fraction which included a broad spectrum of lipoproteins was divided in some cases into $\mathrm{D}<1.006$ and $\mathrm{D} 1.006$
TABLE $\mathrm{V}$

Data on very low density lipoprotein fractions*

\begin{tabular}{|c|c|c|c|c|c|c|c|}
\hline \multirow{2}{*}{$\begin{array}{c}\text { Serum } \\
\text { no. }\end{array}$} & \multirow{2}{*}{$\begin{array}{c}\text { Serum } \\
\text { lactescence }\end{array}$} & \multicolumn{3}{|c|}{$\mathrm{D}<1.006$} & \multicolumn{3}{|c|}{ D $1.006-1.019$} \\
\hline & & TC & PL & TG & TC & PL & TG \\
\hline & & \multicolumn{6}{|c|}{$\mathrm{mg} / 100 \mathrm{ml}$ of serum } \\
\hline $5 a$ & $+t+t$ & 629 & 503 & 2,351 & 26 & 32 & 71 \\
\hline $\begin{array}{r}9 \\
12\end{array}$ & $\begin{array}{l}+++ \\
+++\end{array}$ & $\begin{array}{l}366 \\
360\end{array}$ & $\begin{array}{l}339 \\
236\end{array}$ & $\begin{array}{r}1,047 \\
876\end{array}$ & $\begin{array}{l}20 \\
46\end{array}$ & $\begin{array}{l}22 \\
68\end{array}$ & $\begin{array}{r}38 \\
116\end{array}$ \\
\hline $\begin{array}{l}13 \\
15 \\
18\end{array}$ & $\begin{array}{l}++ \\
++ \\
++\end{array}$ & $\begin{array}{l}227 \\
185 \\
341\end{array}$ & $\begin{array}{l}208 \\
177 \\
244\end{array}$ & $\begin{array}{l}573 \\
458 \\
518\end{array}$ & $\begin{array}{l}17 \\
52 \\
47\end{array}$ & $\begin{array}{l}14 \\
45 \\
45\end{array}$ & $\begin{array}{l}18 \\
64 \\
95\end{array}$ \\
\hline $\begin{array}{l}22 \\
59 \\
28 \\
35\end{array}$ & $\begin{array}{l}+ \\
+ \\
+ \\
+\end{array}$ & $\begin{array}{r}257 \\
118 \\
89 \\
51\end{array}$ & $\begin{array}{r}199 \\
125 \\
104 \\
72\end{array}$ & $\begin{array}{l}373 \\
352 \\
237 \\
270\end{array}$ & $\begin{array}{r}121 \\
24 \\
44 \\
49\end{array}$ & $\begin{array}{l}92 \\
23 \\
40 \\
47\end{array}$ & $\begin{array}{l}93 \\
33 \\
49 \\
76\end{array}$ \\
\hline $\begin{array}{l}40 \\
x x \dagger \\
52 a\end{array}$ & $\begin{array}{l}- \\
-\end{array}$ & $\begin{array}{l}53 \\
32 \\
42\end{array}$ & $\begin{array}{l}47 \\
28 \\
36\end{array}$ & $\begin{array}{l}74 \\
54 \\
63\end{array}$ & $\begin{array}{r}19 \\
179 \\
73\end{array}$ & $\begin{array}{rr}9 & 15 \\
9 & 148 \\
3 & 68\end{array}$ & $\begin{array}{r}17 \\
109 \\
85\end{array}$ \\
\hline
\end{tabular}

* For abbreviations, see footnote to Table II $\dagger$ This serum was obtained during an acute infection and is not included elsewhere.

1.019 subfractions. The $\mathrm{D}<1.006$ portion contained the lactescent material, and the degree of lactescence of the sera was related to the quantity and triglyceride content of this portion. Results of analyses of lipids in the two subfractions are shown in Table V. The protein content of the $\mathrm{D}<1.006$ fraction was very low in proportion to lipid, considerably lower than that of the D 1.006-1.019 fraction, particularly in cases of lactescent sera. Lactescence appeared to be a result of the presence of lipoproteins of very low density which were high in triglyceride and low in protein.

\section{Factors influencing lipoproteins}

It is evident from data already presented that the quantity of serum lipoproteins and the lipoprotein pattern (variations of which were reflected in differences in serum TG and TC/TG) bore a relation to the degree of hypoalbuminemia which in general was a good index of the severity of the nephrotic syndrome. The lipoprotein pattern in particular was also influenced by other factors, as is indicated by the irregular relationship between triglyceride and albumin. There were relatively great day to day variations in triglyceride values even when conditions were apparently stable. The lipid relationships in some cases were altered by hospitalization without spe- 
cific therapy or changes in the disease. Changes in diet, glucose infusions (22), albumin infusions (23), or steroid therapy often resulted in changes in concentrations of individual lipids and in lipoprotein pattern. A large decrease in all lipids, particularly in triglyceride, occurred within 48 hours in one case, during an acute infection complicated by vomiting and diarrhea. Several elderly patients with nephrosis complicated by other diseases (especially malignancies) had unusually low levels of lipids. An attempt was made to eliminate, in so far as possible, the effects of these various complicating factors in the present study.

Lipoprotein pattern seemed to differ somewhat from patient to patient, presumably due to differences in endocrine and metabolic regulation, even when the disease state and the environmental factors discussed above were similar. The same pattern recurred during successive relapses of the disease in some individual patients, and the patterns often remained relatively constant for periods of weeks or months. The patterns, of course, changed from time to time in a majority of the cases, usually in relation to changes in the disease but sometimes without apparent cause. The magnitude and pattern of the lipid alterations often changed as renal insufficiency developed, possibly as a result of the decrease in proteinuria.

\section{DISCUSSION}

It is generally recognized that hyperlipidemia of considerable degree occurs more consistently in nephrosis or in the nephrotic syndrome than in types of renal disease not associated with marked proteinuria or hypoalbuminemia. From this and other evidence (24) it has been suspected that the lipid disturbance in nephrosis may be causally related to the deficiency of albumin, though some contrary evidence has been presented by Heymann, Nash, Gilkey and Lewis (25). The question is complicated by the irregular relationships among the individual lipids themselves, and even if deficiency of albumin is an important cause of the lipid disturbance, it may be that deficiency of other proteins of relatively small molecular size and possibly other entirely different disturbances also play a part. The present observations confirm the existence of a relationship between the levels of the serum lipids and serum albumin in nephrosis but indicate no more than the possibility that the hyperlipidemia is caused by hypoalbuminemia.

As already noted, levels of triglyceride were related irregularly to those of cholesterol and phospholipid, reflecting differences in lipoprotein pattern among the different sera. Total serum cholesterol and phospholipid were increased whenever albumin was decreased but triglyceride was regularly increased only when levels of serum albumin were very low. It is evident from these observations that the mechanisms regulating the concentrations of triglyceride were not identical with those governing the other lipids.

Serum triglyceride level was a good index of the quantity of very low density lipoproteins in the serum, and, in accord with the observations of Albrink, Man and Peters (26), was correlated with the degree of lactescence of the serum. Total serum cholesterol was not always an equally good index of the quantity of D 1.019-1.063 lipoproteins, which normally contain the major portion of serum cholesterol, because of the large amount of cholesterol sometimes present in the $\mathrm{D}<1.019$ lipoprotein fraction. Reasonably accurate estimates of the lipoprotein pattern could be made from a knowledge of both cholesterol and triglyceride levels, or from cholesterol level and the appearance of the serum, but not from cholesterol level alone.

Rosenman, Byers and Friedman (27), from studies on experimental nephrosis in rats, postulated that an accumulation of triglyceride due to a disturbance in the clearing mechanism is the primary lipid alteration in nephrosis, and that cholesterol and phospholipid accumulate passively as a result of trapping by the triglyceride. Lipoproteins were not studied. It appeared in the present study that an increase in cholesterol often occurred in the absence of any significant increase in triglyceride. Evidence of a decreased rate of conversion of $S_{f} 10$ to 400 lipoproteins to those of higher density $\left(S_{f} 3\right.$ to 9$)$ was observed in children with nephrosis by Gitlin and associates (28). This mechanism might explain in part the occurrence of sera of the Group 1 type with increased $\mathrm{D}<1.019$ lipoproteins, but other (perhaps earlier) disturbances must be present to account for increased levels of cholesterol, phos- 
pholipid, and D 1.019-1.063 lipoproteins in sera such as those of Groups 3 and 4 . Knowledge of the biochemical basis of these disturbances is scant.

The composite picture of the lipoprotein alterations in nephrosis which is suggested by this study may be summarized as follows. When nephrosis of mild to moderate degree develops, there is an increase in lipoproteins of D 1.0191.063 and consequently in serum cholesterol and phospholipid, often accompanied by little change from normal in $\mathrm{D}<1.019$ lipoproteins. As the syndrome becomes more severe, the quantity of $\mathrm{D}<1.019$ lipoproteins usually becomes progressively greater and is reflected in an increase in serum triglyceride and lactescence. At the same time, the D 1.019-1.063 lipoproteins fall toward or even below normal. Serum cholesterol and phospholipid continue to increase, but come to be present principally in the $\mathrm{D}<1.019$ instead of the D 1.019-1.063 fraction.

The reason for the inverse relationship between quantities of the $D<1.019$ and the $D$ 1.0191.063 fractions is not clear. A decrease in the $\mathrm{D}<1.019$ fraction and a simultaneous increase in the D 1.019-1.063 fraction have been observed to occur early in remissions of the disease induced by steroid therapy and during the course of repeated albumin infusions. Reciprocal changes in the fractions in the opposite direction sometimes occurred during prolonged infusions of glucose (22). The reciprocity between the fractions probably is not limited to nephrosis but is seen also in some other diseases. The decrease in one fraction as the other increased suggested the possibility of an interaction between lipoproteins of different densities in the serum. The relationship between the fractions seems to be metabolic, however, for in preliminary studies no change in quantity or composition of the fractions was noted when $\mathrm{D}<1.019$ and $\mathrm{D} 1.019-1.063$ lipoproteins were mixed in various proportions and again separated at a density of 1.019 (29).

\section{SUM M ARY}

1. Sera obtained periodically from 44 hospitalized patients with uncomplicated nephrosis (nephrotic syndrome) were analyzed for albumin, lipids, and, in many cases, lipoproteins.
2. Concentrations of total serum cholesterol, phospholipid, triglyceride, and total lipid were related inversely and nonlinearly to serum albumin levels. The relationship between triglyceride and albumin was less regular than that of the others, and the form of the relationship was different.

3. Pattern as well as total concentration of lipoproteins differed among the different sera with increased lipids. Either or both of the $D<1.019$ and the D 1.019-1.063 lipoprotein fractions were abnormally large; however, these two fractions usually were not greatly increased simultaneously. Principally the D 1.019-1.063 lipoproteins were increased in a majority of cases of nephrosis without great deficiency of serum albumin. Severe nephrosis usually was characterized by high levels of the $\mathrm{D}<1.019$ lipoprotein fraction, often with near normal D 1.019-1.063 lipoproteins and subnormal high density (D 1.063-1.21) lipoproteins. Abnormalities were also noted in composition of the lipoprotein fractions.

4. Serum cholesterol and phospholipid were increased whenever the lipoproteins were increased, since both the $\mathrm{D}<1.019$ and $\mathrm{D} 1.019$ 1.063 lipoprotein fractions were rich in these lipids. Serum triglyceride and lactescence were increased appreciably only in sera with increased quantities of $\mathrm{D}<1.019$ lipoproteins.

\section{REFERENCES}

1. Epstein, A. A. The nature and treatment of chronic parenchymatous nephritis (nephrosis). J. Amer. med. Ass. 1917, 69, 444.

2. Daniels, W. B. Plasma-lipoids in renal disease. Brit. J. exp. Path. 1925, 6, 283.

3. Page, I. H., Kirk, E., and Van Slyke, D. D. Plasma lipids in chronic hemorrhagic nephritis. J. clin. Invest. 1936, 15, 101.

4. Peters, J. P., and Man, E. B. The interrelationships of serum lipids in patients with diseases of the kidneys. J. clin. Invest. 1943, 22, 721.

5. Thomas, E. M., Rosenblum, A. H., Lander, H. B., and Fisher, R. Relationships between blood lipid and blood protein levels in the nephrotic syndrome. Amer. J. Dis. Child. 1951, 81, 207.

6. Barr, D. P., Russ, E. M., and Eder, H. A. Proteinlipid relationships in human plasma. II. In atherosclerosis and related conditions. Amer. J. Med. 1951, 11, 480.

7. Kunkel, H. G., and Slater, R. J. Lipoprotein patterns of serum obtained by zone electrophoresis. J. clin. Invest. 1952, 31, 677 . 
8. Shafrir, E. Partition of unesterified fatty acids in normal and nephrotic syndrome serum and its effect on serum electrophoretic pattern. J. clin. Invest. 1958, 37, 1775.

9. Gofman, J. W., Rubin, L., McGinley, J. P., and Jones, H. B. Hyperlipoproteinemia. Amer. J. Med. 1954, 17, 514.

10. Goodman, H. C., and Baxter, J. H. The nephrotic syndrome. Clinical observations on therapy with prednisone and other steroids. J. Amer. med. Ass. 1957, 165, 1798.

11. Havel, R. J., Eder, H. A., and Bragdon, J. H. The distribution and chemical composition of ultracentrifugally separated lipoproteins in human serum. J. clin. Invest. 1955, 34, 1345.

12. Bragdon, J. H., Havel, R. J., and Boyle, E. Human serum lipoproteins. I. Chemical composition of four fractions. J. Lab. clin. Med. 1956, 48, 36.

13. Havel, R. J. Early effects of fat ingestion on lipids and lipoproteins of serum in man. J. clin. Invest. 1957, 36, 848.

14. Bragdon, J. H. Colorimetric determination of blood lipides. J. biol. Chem. 1951, 190, 513.

15. Sperry, W. M., and Webb, M. A revision of the Schoenheimer-Sperry method for cholesterol determination. J. biol. Chem. 1950, 187, 97.

16. Stewart, C. P., and Hendry, E. B. The phospholipids of blood. Biochem. J. 1935, 29, 1683.

17. Rutstein, D. D., Ingenito, E. F., and Reynolds, W. E. The determination of albumin in human blood plasma and serum. A method based on the interaction of albumin with an anionic dye-2-(4'hydroxy-benzeneazo) benzoic acid. J. clin. Invest. 1954, 33, 211.

18. Randolph, M. L., and Ryan, R. R. A slicer for sampling liquids. Science 1950, 112, 528.
19. Gornall, A. G., Bardawill, C. J., and David, M. M. Determination of serum proteins by means of the biuret reaction. J. biol. Chem. 1949, 177, 751.

20. Lowry, O. H., Rosenbrough, N. J., Farr, A. L., and Randall, R. J. Protein measurement by the Folin phenol reagent. J. biol. Chem. 1951, 193, 265.

21. Ahrens, E. H., Jr., and Kunkel, H. G. The stabilization of serum lipid emulsions by serum phospholipids. J. exp. Med. 1949, 90, 409.

22. Baxter, J. H., Goodman, H. C., and Shafrir, E. Effects of glucose infusions on serum lipids and lipoproteins in nephrosis (abstract). J. clin. Invest. 1959, 38, 986.

23. Baxter, J. H., Goodman, H. C., and Havel, R. J. Hyperlipidemia of nephrosis (abstract). J. clin. Invest. 1957, 36, 873.

24. Rosenman, R. H., Friedman, M., and Byers, S. O. The causal role of plasma albumin deficiency in experimental nephrotic hyperlipemia and hypercholesteremia. J. clin. Invest. 1956, 35, 522.

25. Heymann, W., Nash, G., Gilkey, C., and Lewis, M. Studies on the causal role of hypoalbuminemia in experimental nephrotic hyperlipemia. J. clin. Invest. $1958,37,808$.

26. Albrink, M. J., Man, E. B., and Peters, J. P. The relation of neutral fat to lactescence of serum. J. clin. Invest. 1955, 34, 147.

27. Rosenman, R. H., Byers, S. O., and Friedman, M. Plasma lipid interrelationships in experimental nephrosis. J. clin. Invest. 1957, 36, 1558.

28. Gitlin, D., Cornwell, D. G., Nakasato, D., Oncley, J. L., Hughes, W. L., Jr., and Janeway, C. A. Studies on the metabolism of plasma proteins in the nephrotic syndrome. II. The lipoproteins. J. clin. Invest. 1958, 37, 172.

29. Shafrir, E. Personal communication.

\section{CORRECTION}

In the paper entitled "Water and Electrolyte Studies in Cholera" by Watten, Morgan, na Songkhla, Vanikiata and Phillips ( J. clin. Invest. 1959, 38, 1879), the osmolarity values in Tables II and III were erroneously "corrected" according to Eisenman's formula on page 1881 of the paper. 